Wipeout? Entrepreneurship, policy interaction and the EU's 2030 renewable energy target

Oscar W F Fitch-Roy ${ }^{\mathrm{a} *}$, David Benson ${ }^{\mathrm{b}}$ and Catherine Mitchell ${ }^{\mathrm{a}}$

${ }^{a}$ Energy Policy Group, University of Exeter, Penryn, UK

${ }^{b}$ Department of Politics and International Relations, University of Exeter, Penryn, UK

*o.fitch-roy@exeter.ac.uk

Accepted for publication: 4/6/2018 


\title{
Wipeout? Entrepreneurship, policy interaction and the EU's 2030 renewable energy target
}

\begin{abstract}
In 2014, the European Council set energy and climate targets for 2030 that will have far-reaching implications for the decarbonisation of Europe's economy as well as the nature and success of the energy integration project, the Energy Union. The targets mark a qualitative shift towards a more technology-neutral EU climate and energy policy than represented in targets for 2020, decided in 2007. Existing explanations emphasise the role of non-state actors but do not fully account for the muted advocacy for a multiple targets approach. This article examines the alternative explanatory power of the concepts of problem surfing and spillover, taken from the multiple streams approach, for interpreting the inability of multiple targets advocates to make a real impact on the policy agenda. Findings suggest that the problematisation of the EU's 'flagship' instrument, the EU-ETS, by policy entrepreneurs and subsequent structural internal alignment of the policy community offer a complementary explanation.
\end{abstract}

Keywords: European Union; energy policy; problem surfing; multiple streams

\section{Introduction}

In October 2014, European heads of state selected new climate and energy targets for the EU 2030 energy policy framework (European Council 2014). The targets will guide the ambition and nature of EU policy until 2030 and have important implications for Europe's transition to a low-carbon economy and, as central to the Energy Union, for integration prospects in this area (Szulecki et al. 2016). The targets remain politically contested as the European Parliament and the Council of the European Union scrutinise the Clean Energy Package of legislation implementing the measures. The package of measures commits the EU to emit $40 \%$ less greenhouse gas in 2030 than in 1990, to produce $27 \%$ of Union energy consumption from renewable sources, and reducing overall energy consumption by $27 \%$. The decision taken at the European Council was preceded by several years of vigorous interaction between interest groups, the European Commission and the member states. At the same time that the targets were being discussed, important reforms of the EU's emissions trading system were being legislated. During 2013 and 2014, the activity of non-state actors, primarily businesses and NGOs, relative to the 2030 targets amounted to attempts to set the agenda for discussing the framework. Agenda-setting proved contentious with outcomes, as argued below, not entirely amenable to existing academic explanations of the 2030 targets. 
The agenda-setting process was dominated by actors' position on the issue of technologyneutrality - the idea that policy should avoid selecting between decarbonisation technologies and techniques wherever possible. Consequently, two distinct 'sides' to the debate emerged in the policy community, a pro-business, technology-neutral 'single target' side and a proenvironmental 'multiple targets' side, representing environmental NGOs as well as renewable energy and energy efficiency producer groups. The single target side favoured an approach to climate policy in which a single greenhouse gas (GHG) emissions target is pursued through the creation of a price signal in the EU emissions trading system (EU ETS). Multiple targets advocates, in contrast, argue in favour of sectoral targets for renewable energy supply and energy efficiency. The sustainable energy debate has been characterised by polarised attitudes to technology-neutrality for many years. An equilibrium view of economics lends support to technology-neutrality while research on sustainability transtitions suggests that technologyspecific policy such as multiple targets may be required to transform a sector such as energy (Mitchell, Bauknecht, and Connor 2006; Woodman and Mitchell 2011; Mitchell 2010; Ringel 2006; Helm 2012; Grubb, McDowall, and Drummond 2017).

The idea of a single target garnered a large constituency of primarily (but not exclusively) business supporters within the policy community, seeking a less prescriptive policy outcome and was strongly supported by powerful European Commissioners such as Energy Commissioner, Günther Oettinger. Meanwhile, renewable energy and energy efficiency industry groups, along with environmental NGOs (ENGOs) promoted a more technologytargeted approach featuring strong targets for renewable energy and energy efficiency. The ability of this second group to influence the policymaking agenda was observed to be remarkably muted, which is surprising given the important role played in 2007 by these interests in establishing a strong multiple target policy for 2020 (Boasson and Wettestad 2013).

Unlike the earlier package, which specified the proportion of energy each member state must derive from renewable sources, the 2030 framework features a relatively unambitious target for renewable energy (Commission modelling projected $24-27 \%$ in the absence of a target) and, that binds only at the EU level (Bürgin 2015; European Commission 2014a). By this measure, although the 2030 framework features three headline targets, the increased emphasis on emissions trading rather than mandated expansion of renewables or energy savings represents a policy that is more 'technology-neutral', than the $20 / 20 / 20$ policy. The shift towards a more technology-neutral energy policy is significant not only because it is 
indicative of power dynamics within EU lobbying on climate and energy policy but also because it challenges much of the burgeoning literature on sustainability transitions and transformations. Economic research on EU climate policy (often leading on from Dales 1968 and; Tietenberg 1985) often prescribes an economy-wide carbon price as the most efficient means of reducing emissions, an assumptions not typically questioned when analysing the political drivers and implications (Wettestad 2014; Wettestad and Jevnaker 2016). The transitions literature, in contrast, suggests that a successful energy system transformation - a “messy, conflictual, and highly disjointed process" (Meadowcroft 2009, 324) - is likely to require policy intervention focussed on specific technologies, rather than simply 'allowing the market' to choose between low-carbon energy alternatives (Solomon and Krishna 2011; Lehmann and Gawel 2013). The observed significance of the idea of technology-neutrality in structuring the agenda-setting process, the weakness of the pro-multiple targets lobby and the shift in EU climate and energy policy towards a more technology-neutral approach therefore raise the question: why was multiple targets advocacy so muted, especially compared to 2007 when it was apparently potent?

Existing explanations for the general outcome of the 2030 targets centre on the importance among non-state actors, especially business interests and the actions of specific, powerful pro-business EU officials, as well as mixed political signals from the member states and a divided Commission (Bürgin 2015; Fuchs and Feldhoff 2016; Ydersbond 2016). However, we argue below that these explanations do not fully account for the muted support for multiple targets among non-state actors, or the impact of the EU-ETS reform process on actors that were lobbying both briefs at the same time. In this article, we accept from these earlier studies that the explanation for more business-friendly 2030 targets lies partially with the role played by non-state actors, especially business, as well as with the dynamics of the College of Commissioners. However, we also propose that the relative lack of power exerted by renewable energy groups and ENGOs in favour of a strong renewable energy target remains unaccounted for and requiring further explanation.

To this end, we use the results of on an empirical study built on extensive documentary analysis and thirty-two interviews conducted between April 2015 and April 2016 with members of the European institutions and a broad range of actors working for NGOs and businesses selected for their familiarity with the setting of the 2030 targets. We draw on the multiple streams approach (MSA) developed by Kingdon (2010) to assess whether MSA and associated concepts could help interpret entrepreneurial non-state actors' influence on the 
policy agenda. The approach has been applied to various facets of EU policymaking (Zahariadis 2008; Ackrill, Kay, and Zahariadis 2013; Ackrill and Kay 2011). Moreover, the basic causal mechanisms of MSA, policy window opening and stream coupling, are shown as broadly applicable to EU energy policy making (Herweg 2016). In fact, the MSA has been found to interpret some of the EU's peculiarities such as 'institutional fluidity, jurisdictional overlap, endemic political conflict, policy entrepreneurship and varying time cycles' (Ackrill, Kay, and Zahariadis 2013, 871). We therefore hypothesise that, given their overt focus on policy entrepreneurship, the MSA concepts of 'problem surfing' and 'spillover' can help to answer our research question.

This article presents a structured analysis. Firstly, we discuss the main theoretical propositions forwarded by Kingdon's multiple streams approach (MSA). Secondly, we present an overview of the historical development of the 2030 climate and energy framework, with a particular focus on agenda-setting and renewable energy policy. Thirdly, we discuss why existing explanations, although compelling, do not account for the muted role of multiple targets advocates and then assess the relative ability of problem surfing and spillover to aid interpretation. Finally, conclusions reflect on the implications of the research for the EU studies literature and future research.

\section{Surfing problems and setting the agenda}

Agenda-setting provides significant influence over the policy process and its outcomes (Cobb and Elder 1972). With many competing claims for attention, problems' 'moment in the sun' may be short lived and attention given to them cyclical (Downs 1972). John Kingdon's multiple streams approach (MSA) to understanding agenda-setting, first published in 1984, still remains the subject of lively scholarly discussion (Herweg 2015, 2016; Winkel and Leipold 2016; Herweg, Huß, and Zohlnhöfer 2015; M. D. Jones et al. 2016; Weible and Schlager 2016; Cairney and Jones 2016). The enduring appeal of MSA is its ability to see problems, potential policy solutions and the political context developing largely independently, only to be brought together by policy entrepreneurs, resourceful and talented actors who can 'do more with less', during brief critical junctures known as policy windows (Kingdon 2010; Zahariadis 2014; Mintrom and Norman 2009). Kingdon's conception of independent problem and policy streams allows for solutions to pre-date problems, with advocates often seeking to strategically present the same solution to a variety of salient problems over time (Kingdon 2010). For some advocates, this is clearly the case. A company involved in energy production, for example, has a clear interest in repeatedly presenting its 
products as the solution to the most salient problems at any particular time. This kind of 'problem surfing' is recognised as an opportunistic policy advocacy strategy (Kingdon 2010, $165)$.

The aim of such strategic presentation and re-presentation by advocates of the same solution to an ever-evolving series of problems is to 'catch a problem wave' which will 'bring them to shore' or help them realise their policy preferences (Kingdon 2010, 165). Building Kingdon's central insight that policies often predate problems and that problems reflect changes in the political and physical world, later authors refine the metaphor, describing 'problem surfing' as advocates 'continuously searching the problem stream...in search of the next big wave'.

\section{Problem surfing: a bundle of concepts}

Policy entrepreneurs apply policies to problems during periods Kingdon describes as 'policy windows'. These windows of opportunity are open for a finite duration and see advocates of particular policies push their proposals or bring attention to a specific problem. Windows may open to due unpredictable external events or may open regularly due to predictable timetables. The coupling of the policy and problems streams occurs only during a policy window. In MSA it is assumed that policy actors themselves do not control when the window opens (Boscarino 2009; Kingdon 2010).

While the meaning of the term that prompts this article is that used by Kingdon (2010) and built upon by Boscarino (2009), the surfing metaphor has been used to describe various types of political behaviour (for example; Inoguchi 1979, 2016; Kayser 2005; Chowdhury 1993). In general, political surfing is presented as opportunistic behaviour. Actors adapt in response to shifts in their extant structural context but over which they have little or no agency. It is assumed by authors using the term that this pattern mirrors surfers seeking to catch and ride ocean waves.

Superficially, the metaphor rings true. Most individual actors cannot control large-scale political events like a gas supply crisis or the rise of populist sentiment any more than a surfer can control the ocean. While a policy window represents the coupling of the three streams, a problem wave exists only in the problem stream. Unlike the opening of a policy window, the 'breaking' of a problem wave does not have causal properties and is not sufficient, on its own, to bring about policy change. As an advocacy strategy problem surfing bundles both framing and problem definition. 


\section{Framing}

Framing is a strategy by which an entrepreneurial policy actor exploits issue ambiguity to 'spin' its characteristics through emphasising particular aspects of the problem or its solution (Eising, Rasch, and Rozbicka 2015; Boräng et al. 2014; Klüver, Mahoney, and Opper 2015; Voltolini and Eising 2016). Framing is, in effect, a communications technique that selectively highlights some features of reality while omitting others (Entman 1991). Environmental groups such as ENGOs have historically been shown as especially adept at framing the 'issues' which 'form the debate' (Rawcliffe 1998, 9). Despite the importance of framing in influencing policy outcomes, the understanding of how it functions within and across policy domains remains relatively underdeveloped, although an increasing number of studies are using quantitative ‘large-n’ techniques (Klüver 2011; Klüver, Mahoney, and Opper 2015; Boräng et al. 2014).

\section{Problem definition}

Numerous authors have explored the concept of problem definition (Rochefort and Cobb 1994; B. D. Jones and Baumgartner 2005; Baumgartner and Jones 2015). Defining and interpreting the problems faced by society is an important means by which influence over the policy agenda may be wielded (Hogwood and Gunn, 1984). Policy entrepreneurs play an important role in defining climate governance problems (Mintrom and Luetjens 2017). From a political perspective, the conditions, difficulties or issues that exist in the world do not have fixed causal properties, rather 'political actors deliberately portray them in ways calculated to gain support for their side' (Kingdon, 2010; Stone, 1989 p281). Actors may work to introduce 'new' problems to the policy process or redefine 'old' problems that have circulated for some time (Kingdon 2010). In general, conditions or issues that are convincingly presented as severe, proximate, frequent or novel are more likely to enter or remain on agenda than those that are not (Rochefort and Cobb 1994). In a policy environment already densely populated by potential problems, the rhetoric of 'crisis' or 'emergency' is a common strategy for claiming special attention for an issue (Rochefort and Cobb 1994, 21).

\section{Spillover}

Kingdon (2010) borrows the term 'spillover' from Ernst Haas' 1958 (1958) neofunctionalist approach to European integration in describing the effect that action in one policy arena may have on another. Kingdon suggests that spillover may occur when a principle is established or a precedent set which alters the terms under which a policy topic is discussed in the future. Kingdon also suggests that success by a policy entrepreneur in one area may affect what happens in other, adjacent or overlapping policy area. This could be because a particular 
policy idea, once shown to be successful in one field then becomes attractive to entrepreneurs seeking success in another. It could also be the case that "...the coalition that was built and nurtured to establish the new policy can be transferred to other fights" (Kingdon 2010, 192).

The spillover mechanism, although loosely defined in Kingdon's original 'precedent-setting' formulation, has received more recent attention. Ackrill and Kay (2011) illuminate a distinction between Kingdon's prediction of spillover across unconnected policy arenas (exogenous spillover) and spillover between institutionally connected areas (endogenous spillover). They argue that endogenous spillovers can hold windows of opportunity open, creating greater space for policy change.

\section{Non-state actors and the 2030 targets agenda}

Having set out the conceptual basis for the analysis, this section presents an account of the activity of non-state actors in the agenda-setting process that preceded the European Council in October 2014 at which the 2030 targets were agreed.

In 2007, the European Council agreed targets that constituted the 20/20/20 framework, which provides us with a baseline for assessment of how EU climate and energy policy may change over time (Bürgin 2015). These targets commit the EU to improve energy efficiency by $20 \%$, to reduce greenhouse gas emissions by $20 \%$ (compared to 1990) and to increase energy produced from renewable sources to 20\% - all by 2020 (European Council 2007). These targets were considered ambitious for the EU and, importantly, the renewable energy target allowed for the calculation of specific mandatory targets for each member state. Policy entrepreneurship by multiple target advocates in civil society, especially the renewable energy producer industries, as well as the European Parliament, proved significant in agendasetting (Boasson and Wettestad 2013). These ambitious, binding targets were part of a technology-specific policy framework that clearly specified renewable energy as one means for meeting the EU's longer-term goals; in 2009, the European Council stated its ambition to reduce greenhouse gas emissions by 80-95\% compared to 1990 by 2050 (European Council 2009).

After the disappointing UN Framework Convention on Climate Change COP 15 in Copenhagen in 2009, the EU needed to update its climate and energy policy before it expired in 2020. While the nature and scope of the post-2020 policy remained unclear, some nonstate actors, encouraged by the European Commission, began to broadly delineate the debate. The merits of renewable energy and energy efficiency as part of a 'no regrets' long-term 
policy package were introduced through well regarded analyses by environmental actors, such as the European Climate Foundation (ECF) (European Climate Foundation 2010). The ECF reports countered more 'carbon-price-only' approaches being discussed by the electricity industry (Eurelectric 2009). There followed a flurry of reports, largely derivative of this earlier work, discussing the 2050 goals from a range of perspectives (e.g. Greenpeace 2010; EREC 2010; Eurogas 2011; European Gas Advocacy Forum 2011; WWF 2012).

A timetable for international climate diplomacy then emerged from the UN Durban conference 2011, identifying 2015 as a critical deadline for a universal agreement. The last European Council of 2014 then became the date for the EU to announce its post 2020 climate ambition (UNFCCC 2012a, 2012b, 2014). In 2011, the Commission produced a 'roadmap' establishing $40 \%$ as the new optimum emissions reduction target, achievable by 2030 . Despite being the lowest figure that the Commission's modelling suggests to meet the 8095\% 2050 goal, the $40 \%$ figure was not seriously challenged by ENGOs, possibly because they were attempting to appear 'reasonable and constructive' (Interview 2).

The 'energy roadmap 2050' is ambivalent about the nature of the policy framework but describes sustained growth in renewables and improved energy efficiency as 'no regrets' options (European Commission 2011a, 2011b). Following analyses by the Commission and other stakeholders, including interest groups, it was clear that the next logical step was a 2030 climate and energy policy to be proposed at the autumn 2014 European Council (Interview 17). The European Commission's 2013 green paper therefore proposed new targets for 2030 and explicitly sought to elicit whether the framework should feature a multiple or single GHG reduction target approach (European Commission 2013). Lobbying by ENGOs and business groups on the policy began in earnest and the idea of a more technology-neutral policy entered the agenda (Interview 2, 4, 8).

Throughout 2013, the European Renewable Energy Council (EREC), which helped coordinate the renewable energy sector's strong stance in favour of multiple targets in 2007, was unravelling (EREC 2013; Boasson and Wettestad 2013). Following a real-estate dispute over a building that EREC rented and sub-let to various trade associations, EREC was mired in legal action and suffering diminished income from the departure of the largest trade associations. The drain on financial and human resources made it more difficult for EREC to plan and coordinate multiple-target advocacy as effectively as it had in 2007 (Interview 13). EREC was formally liquidated in spring 2014 (Politico 2014; Beckman 2014). 


\section{Overlap with ETS reform}

One major problem identified as important in the climate and energy policy community in 2013 was the performance of the EU Emissions Trading System (or EU-ETS). Implemented in 2005, the EU-ETS is the world's first and most comprehensive international greenhouse gas (GHG) cap-and-trade system and covers around half of EU emissions (European Commission 2016). The mere existence of a functioning EU-ETS is regarded as a major policy success for the European Union (Convery 2009; Oberthür 2011). Among other factors, the successful introduction of the system was dependent on acquiescence from key, typically resistant industries, achieved partly by reframing emissions trading as a cost-efficient approach to climate mitigation (Voß 2007).

As well as seeking to lock member states into a gradually strengthening emissions reduction regime, the institutional embeddedness and the costs sunk in its creation mean that the ETS plays a central role in EU energy and climate policymaking (Bailey, Gouldson, and Newell 2011; Woerdman 2004). While the system continues to evolve, the immutable status of the principle of cap and trade is often expressed by describing the ETS as Europe's 'flagship' or 'cornerstone' climate policy (Wettestad 2014; Skjærseth and Wettestad 2010; Groenenberg et al. 2008; Convery 2009; Braun 2009). The EU-ETS itself also arguably creates a selfreinforcing constituency of support within which the continuation of the instrument has become an end unto itself (Voß and Simons 2014).

By 2013, the performance of the policy had become a source of significant concern (Wettestad and Jevnaker 2016). In particular, during 2012 and 2013, an oversupply of allowances developed and the Emission Trading Allowance (EUA) price fell below $€ 10$ per tonne, a level deemed too low to meaningful impact investment decisions in the energy sector (for example, EWEA 2014; IETA 2012; European Commission 2014a). Many observers concluded that the EU-ETS was failing (Interview 7, 25). This sense of concern was summarised by a DG Energy official:

'[The] ETS price has never driven any investment, not even the management of existing assets from a company, the $\mathrm{CO}_{2}$ price has never driven the running or nonrunning of a renewables versus coal power plant of a given portfolio of a company'

The chief climate change advisor for Shell, a firm supporter of a 'strong, reformed ETS' (Interview 25) concedes that by 2014 : 
'...many now perceive that the EU-ETS has become more of a compliance formality than an investment driver' (Hone 2017, 105)

The Commission response was a package of ETS reforms, including 'backloading' or temporarily withholding allowances scheduled for market auction. A proposal was adopted by the Parliament and the Council in $2013^{1}$. Secondly, the Commission proposed permanent, structural ETS reform through a 'Market Stability Reserve' (MSR) that allows the number of permits issued to the market to vary according to the number of allowances in circulation. The Commission MSR proposal, was adopted in 2015 and will enter operation in 2019 (European Commission 2014c; European Parliament 2014; Wettestad and Jevnaker 2016). Therefore, in 2013, the climate and energy policy community in Brussels simultaneously had two major policy developments in play. Advocacy groups were seeking to influence both the 2030 framework and reforms to the ETS, most notably backloading (Interview 9, 18).

Established to advocate for EU-ETS reform, an informal, ad-hoc coalition of more than 40 organisations, the 'Friends of ETS' coalition brought together an uncommonly broad range of organisations and interest groups (Interview 1,21). Energy utilities, the wind industry, a furniture brand, think-tanks, oil companies, manufacturers of energy efficiency equipment and energy generation plant were all represented alongside industry groups Eurelectic and Eurogas. Although not visible on the group's formal publications, at the heart of the coalition was Change Partnership, a small climate NGO in Brussels, with a CEO whose political judgment and policy knowledge was well regarded (Interview 8, 15, 26, 31). The coalition was financially supported by the European Climate Foundation (ECF) among other donors (Interview 30; Change Partnership 2014). Despite being a small ENGO with limited resources, Change Partnership, through the creation of Friends of ETS, was able to 'punch above its weight', a hallmark of policy entrepreneurship (Boasson and Huitema 2017, 1345).

Acknowledging the 'special' status of the EU-ETS as the EU's climate policy flagship and the sunk costs associated with its establishment, an important part of the group's strategy was to opportunistically frame the perceived failure of the emissions trading system as the most pressing problem facing EU climate and energy policy (Interview 30).

Friends of ETS saw to it that:

\footnotetext{
${ }^{1}$ Decision No 1359/2013/EU
} 
'...every single bit of coverage leading up to any communication from the Commission [on energy and climate] we said, 'We have a crisis in the ETS', Even if it's a different subject. So energy efficiency... You know, the energy efficiency debate meant that that was getting all the coverage [so], every time somebody spoke about energy efficiency, the whole discussion was about ETS...And we're always associated [with] the crisis.'

To underline their position, the group went as far as to diagnose the problem as resulting partially from interaction between the EU-ETS and technology specific policies such as the 2012 Directive designed to implement the earlier 2020 energy efficiency target.

'[We said that] ..." the Energy Efficiency Directive will destroy the ETS, because it will create additional surplus". ... we said up front "it's going to kill the ETS, it's a disaster, we have to do something!",

This tactic, also aggressively employed by fossil fuel industry groups, such as the 'Single Target Coalition' to argue for a single 2030 target (Interview 1, 3, 25), appears to have been successful. Greater coordination on the issue between electricity producers, NGOs and other businesses is credited with contributing to both the short-term goal of backloading and the longer-term MSR fix for the ETS (Interview 8, 30, 31; Wettestad and Jevnaker 2016).

The group's membership was diverse and included several of the industries and nongovernmental voices strongly in favour of a multiple targets approach visible in the earlier debate about the 2020 targets (Interview 4). For example, following the collapse of EREC throughout 2013, elements of the renewable energy industry were able to align with the Friends of the ETS in the absence of a functioning EU-level umbrella organisation (Interview 13). The existence of the coalition and the terms of its membership - adherence to the ETS crisis narrative - posed problems for the 2030 target negotiation (Interview 8, 30). Joining the coalition meant that its membership was constrained in discussions around whether the 2030 targets should be technology specific or technology-neutral: “we simply couldn't talk about multiple targets" (Interview 30). Consequently, lobbying in favour of multiple targets was muted. It was either intellectually incoherent or politically disadvantageous for actors that would typically favour multiple targets to argue for strong technology targets while participating in the Friends of ETS coalition and ETS reform campaign (Interview 8, 9, 21).

Lobbyists and policymakers both sensed that, during the autumn of 2013, stalemate had been reached between multiple and single target positions (Interview 8, 10; Euractiv 2013a, 
2013b). The disagreement among member states, civil society and within the Commission caused the 2030 package to become what President Barroso described as particularly "politically sensitive" (European Commission 2014b, 23). Energy efficiency advocates successfully connected energy security concerns arising from events in Ukraine in $2014^{2}$ with policies to reduce energy consumption (Interview 10). Intervention by several member states in late 2013 and early 2014, in favour of targets for renewable energy and energy efficiency, put pressure on the Commission President for a compromise proposal. The targets that emerged were broadly designed to satisfy supporters of a single target on GHG emissions with weak, non-binding targets for renewable energy and energy efficiency.

This section has shown that while the 20/20/20 debate in 2007 was dominated by the idea of technology-specific targets, at the end of 2013, it appeared that the idea of a single target was rising up the policy agenda, raising questions over why this was occurring. The following section therefore discusses the account relative to existing explanations and MSA concepts of problem surfing and spillover.

\section{Discussion: Surfing the ETS}

For a policy community to debate a topic, issues tend to become essentially uni-dimensional with actors' preferences in most cases assuming a position at some discrete point between two polarised extremes. This 'structuring of the policy conflict' occurs largely to enable coalitions to be built that are either 'for' or 'against' something (Baumgartner et al. 2009, 57). As described above, during 2013 and 2014, the EU climate and energy policy community's range of policy preferences collapsed from a vastly complex debate into single-target versus multiple-target positions. Other than some heavy-industrial interests that sought to limit any and all climate policy, most business interests adopted the single target position while ENGOs, as well as producer groups in the renewable energy and energy efficiency industries took a multi-target position.

In addition to Europe's tarnished role as a global climate leader following a disappointing showing at COP15, the ongoing economic crisis was highly salient in 2013. These factors, acting as what Kingdon (2010) describes as 'focusing events', shifted attention towards 'cost

\footnotetext{
${ }^{2}$ Gas supplies were cut to Ukraine on 16 June 2014 leading to speculation about disrupted gas supplies to the EU the following winter, especially in the Baltic region and some Eastern European member states (Dickel et al. 2014).
} 
efficiency' and minimisation of action, limiting the room for manoeuvre of non-state policy entrepreneurs to push for more ambitious policy. Existing explanations of the 2030 framework acknowledge that non-state business actors enjoyed significant power over the policy agenda, which was strengthened by divisions within the European Commission and the actions of particular business-friendly Commissioners, contributing to targets that were more 'technology-neutral' than the 20/20/20 targets (Fuchs and Feldhoff 2016; Bürgin 2015). These explanations are corroborated by our research. For example, there were divisions within the European Commission on the topic of the 2030 targets. DG Energy favoured multiple targets, especially the units responsible for renewable energy and energy efficiency, while DG Climate Action tended to prefer a 'technology-neutral' approach that emphasised the EU-ETS. This may reflect the career-long commitment of senior DG Climate Action officials who placed carbon pricing at the heart of EU climate policy. There were also vertical rifts within the Directorates General that reversed those across the services: Climate Commissioner Connie Hedegaard was seen as more open to multiple targets than Energy Commissioner, Günter Oettinger. The latter's insistence on weak climate targets only softened in response to guarantees of weak renewable energy and energy efficiency targets, as discussed by Bürgin (2015). Concurrently, the will of the member states was unclear, with Germany internally conflicted due to federal elections meaning that it was not the strong multi-target counterweight to the UK's insistence on a single target approach that it was in 2007 (Interview 3, 11, 13, 2, 22; Bürgin 2015). In this context, the policy window was narrow and policy entrepreneurs' scope to act was limited.

Problematically, these explanations do not account for the muted activity of non-state actors that supported strong and binding targets for renewable energy, providing an evident gap in our understanding. This position is especially puzzling given the central role they played in negotiating the 2020 targets in 2007 (Boasson and Wettestad 2013). By focusing on the policy formulation stage of the policy development, Bürgin's account skates over several years of negotiation by the Commission's services, lobbyists and interest groups that defined the terms of the debate that the College of Commissioners was to have in 2014. Without the 'stalemate' between single and multiple target positions, observed to have occurred by the end of 2013, Commissioner Oettinger's scope to bargain would have been greatly reduced. Our account shows that, by the time the College of Commissioners came to discuss the targets in early 2014 (European Commission 2014b), the idea of a single, technology-neutral 
target was already well established. Our article's contribution is consequently to offer a complementary explanation.

MSA concepts of problem surfing and spillover could take us some way towards this goal and suggest alternative mechanisms by which the voices of multiple targets advocates were subdued. The account given above shows how, in the absence of a wide-open policy window, a policy surfing strategy by the Friends of ETS successfully framed the poor performance of the EU-ETS as the major challenge of EU climate and energy policy in order to contribute to securing backloading and, later, the market stability reserve. Through the creation of the coalition and wider consensus around the ETS crisis narrative, the action spilled over into the debate about the 2030 targets and locked members of the policy community into de facto support for a single target approach, or at least silence on the issue. The result was muted support for a multiple, technology specific targets package for the 2030 framework. This partly explains why, by end of 2013, the Commission perceived a stalemate that was only resolved through bargaining in the College of Commissioners and last-minute intervention from key member states. It also augments existing explanations of why the final package marks a distinct shift, away from the strongly multiple target approach taken in 2007.

The findings have some implications for both the concept of problem surfing and for the multiple streams approach more generally. Firstly, the concept of problem surfing, a kind of problem orientated strategy for policy advocacy as determined by Kingdon (2010) and built on by Boscarino (2009) has some merit in explaining the actions of policy advocates in EU climate and energy policy with the strategy a key part of efforts to secure EU-ETS reform. However, both Kingdon and Boscarino implicitly assume that problem surfing, if effective, will result in positive outcomes for the surfer. In the worst case it is assumed that pushing an idea into the wrong policy window or at the wrong moment simply leads to the proposal or campaign 'fizzling out' or being 'destroyed on the reef' (Kingdon 2010, 171). However, the findings above show that something more complex and potentially damaging to the surfer may occur, especially when the coalition structures assembled to surf a particular problem may have influence on collateral policies.

For this kind of outcome to occur, several conditions need to be met. Firstly, two of what Kingdon describes as open 'policy windows' need to coincide, focused on separate but closely related policy issues, in this case ETS reform and the 2030 targets. Secondly, the policy community must structure itself to respond to one policy window in a way that effects 
the range of possible outcomes in the second. This study shows that one means by which this may happen is through the creation of advocacy coalitions with diverse membership; something that is likely to require an entrepreneurial broker to resolve policy conflict between members (Quirk 1989; Baumgartner et al. 2009).

Third, the problem-surfing strategy in one policy window must correspond to the structure of the policy conflict in the second. Above, we have described how, the creation of a coalition founded on a strategy of emphasising problems with the EU-ETS corresponded with the polarisation of the debate about the 2030 targets into two camps. That the debate about the 2030 targets was defined by actors' position on the idea of technology-neutrality is significant since it has been shown to be a deep and recurring rift in the debate about sustainable energy policy.

Kingdon predicts the possibility of spillover between policy windows, but only insofar as it expects the transfer of proven strategies and coalitions from one issue or area to another (Kingdon 2010). Ackrill and Kay (2011) distinguish between Kingdon's 'political precedent' spillover effect (exogenous spillover) and spillover effects between 'adjacent' policy areas (endogenous spillover). The effect described here is an example of endogenous spillover. Not only do we add further evidence that events in one policy arena can cause changes in another connected area, as shown by Ackrill and Kay, we also show that this kind of spillover can shut down as well as open up the possibility of policy entrepreneurship.

Finally, on a more critical reading the findings cast some doubt on one of the fundamental assumptions of MSA. That the streams may be less independent that Kingdon suggests has been a point of criticism (Mucciaroni 1992; Bendor, Moe, and Shotts 2001). By electing to 'surf' a particular problem (EU-ETS) in one policy window, environmentally minded actors appear to have been constrained into a particular policy position (single target or technologyneutrality) in another (the 2030 framework). The EU-ETS is clearly a policy, even if a rather problematic one, providing some ambiguity over how it should be treated within MSA, the potential for interdependence between the policy and problem streams is obvious.

\section{Conclusions}

The aim of this article is to account for the muted ability of interest groups in favour of a strong renewable energy target to influence the agenda for the EU's 2030 climate and energy policy. We show that policy entrepreneurship by the CEO of Change Partnership in the creation of the Friends of ETS led to a significant alignment within the policy community in 
relation to the EU-ETS. This alignment spilled over into the policy debate about the 2030 targets, preventing some actors from taking a strong position in favour of multiple targets, which we argue helps to explain the shift in policy between 2007 and 2014. These findings contribute to a the growing area of research into the role of policy entrepreneurs in climate policy (Boasson and Huitema 2017).

We are not the first to report the significance of the timing of and interaction between the two policies. Wettestad and Jevnaker $(2016,96)$ identify the side deals that secured support from sceptical central European member states for the 2030 framework as a critical catalyst for achieving structural reform of the EU-ETS. Less has been said, however, about effects in the other direction. That is, how the structuring of the policy community seeking to influence the EU-ETS might have affected the character of the 2030 targets. We find that the MSA concepts of strategic 'problem surfing' and 'spillover' are helpful in answering the research question and provide an additional perspective to the literature in this area, although there remain numerous unanswered questions about both concepts. Whether or not the combination of factors set out in this article is important in other EU policy areas is also unclear and a topic for further research.

\section{Acknowledgements}

The authors are grateful for the helpful discussions about an earlier version of this paper at ECPR general conference in Oslo, September 2017. We also thank two anonymous reviewers for their thoughtful and constructive comments. 


\section{References}

Ackrill, Robert, and Adrian Kay. 2011. "Multiple Streams in EU Policy-Making: The Case of the 2005 Sugar Reform." Journal of European Public Policy 18 (1): 72-89. https://doi.org/10.1080/13501763.2011.520879.

Ackrill, Robert, Adrian Kay, and Nikolaos Zahariadis. 2013. "Ambiguity, Multiple Streams, and EU Policy." Journal of European Public Policy 20 (6): 871-87. https://doi.org/10.1080/13501763.2013.781824.

Bailey, Ian, Andy Gouldson, and Peter Newell. 2011. "Ecological Modernisation and the Governance of Carbon: A Critical Analysis." Antipode 43 (3): 682-703. https://doi.org/10.1111/j.1467-8330.2011.00880.x.

Baumgartner, Frank R., Jeffrey M. Berry, Marie Hojnacki, David C. Kimball, and Beth L. Leech. 2009. Lobbying and Policy Change: Who Wins, who Loses, and Why. University of Chicago Press. https://doi.org/10.1017/CBO9781107415324.004.

Baumgartner, Frank R., and Bryan D. Jones. 2015. The Politics of Information: Problem Definition and the Course of Public Policy in America. Chicago: University of Chicago Press.

Beckman, Karel. 2014. "European Renewable Energy Council Forced into Liquidation." Energypost.eu. 2014. http://www.energypost.eu/european-renewable-energy-councilforced-liquidation/.

Bendor, Jonathan, Terry M. Moe, and Kenneth W. Shotts. 2001. "Recycling the Garbage Can: An Assessment of the Research Program." American Political Science Review 95 (1): 169-90. https://doi.org/10.2307/3117636.

Boasson, Elin Lerum, and Dave Huitema. 2017. "Climate Governance Entrepreneurship: Emerging Findings and a New Research Agenda." Environment and Planning C: Politics and Space 35 (8): 1343-61. https://doi.org/10.1177/2399654417730713.

Boasson, Elin Lerum, and Jørgen Wettestad. 2013. EU Climate Policy: Industry, Policy Interaction and External Environment. Oxford: Ashgate Publishing, Ltd.

Boräng, Frida, Rainer Eising, Heike Klüver, Christine Mahoney, Daniel Naurin, Daniel Rasch, and Patrycja Rozbicka. 2014. "Identifying Frames: A Comparison of Research Methods." Interest Groups \& Advocacy 3 (2): 188-201. https://doi.org/10.1057/iga.2014.12.

Boscarino, Jessica E. 2009. "Surfing for Problems: Advocacy Group Strategy in U.S. Forestry Policy." Policy Studies Journal 37 (3): 415-34. https://doi.org/10.1111/j.15410072.2009.00321.x.

Braun, Marcel. 2009. "The Evolution of Emissions Trading in the European Union - The Role of Policy Networks, Knowledge and Policy Entrepreneurs." Accounting, Organizations and Society 34 (3-4). Elsevier Ltd: 469-87. https://doi.org/10.1016/j.aos.2008.06.002.

Bürgin, Alexander. 2015. "National Binding Renewable Energy Targets for 2020, but Not for 2030 Anymore: Why the European Commission Developed from a Supporter to a Brakeman.” Journal of European Public Policy 22 (5): 690-707. https://doi.org/10.1080/13501763.2014.984747. 
Cairney, Paul, and Michael D. Jones. 2016. “Kingdon's Multiple Streams Approach: What Is the Empirical Impact of This Universal Theory?" Policy Studies Journal 44 (1): 37-58. https://doi.org/10.1111/psj.12111.

Change Partnership. 2014. "Friends of ETS." Changepartnership.org. 2014. http://www.changepartnership.org/campaigns/friendsofets/.

Chowdhury, Abdur R . 1993. "Political Surfing over Economic Waves: Parliamentary Election Timing in India." American Journal of Political Science 37 (4): 1100-1118.

Cobb, Roger, and Charles D. Elder. 1972. Participation in American Politics: The Dynamics of Agenda Building. Boston: Allyn and Bacon.

Convery, Frank J. 2009. “Origins and Development of the EU ETS.” Environmental and Resource Economics 43 (3): 391-412. https://doi.org/10.1007/s10640-009-9275-7.

Dales, J.H. 1968. Pollution, Property and Prices: An Essay in Policy-Making and Economics. Cheltenham: Elgar.

Dickel, Ralf, Elham Hassanzadeh, James Henderson, Anouk Honoré, Laura El-Katiri, Simon Pirani, Howard Rogers, Jonathan Stern, and Katja Yafimava. 2014. "Reducing European Dependence on Russian Gas: Distinguishing Natural Gas Security from Geopolitics." Oxford. http://www.oxfordenergy.org/wpcms/wp-content/uploads/2014/10/NG-92.pdf.

Downs, Anthony. 1972. "Up and Down with Ecology-the Issue-Attention Cycle." Public Interest 28: 38-50.

Eising, Rainer, Daniel Rasch, and Patrycja Rozbicka. 2015. "Institutions, Policies, and Arguments: Context and Strategy in EU Policy Framing." Journal of European Public Policy 22 (4). Taylor \& Francis: 516-33. https://doi.org/10.1080/13501763.2015.1008552.

Entman, Robert M. 1991. "Framing U.S. Coverage of International News: Contrasts in Narratives of the KAL and Iran Air Incidents." Journal of Communication 41: 6-27. https://doi.org/10.1111/j.1460-2466.1991.tb02328.x.

EREC. 2010. "RE-Thinking 2050: A 100\% Renewable Energy Vision for the European Union."

2013. "Hat-Trick 2030 Renewable Energy Energy Efficiency Greenhouse Gas." Brussels. http://www.erec.org/fileadmin/erec_docs/Documents/Publications/EREC_Hattrick2030_April2013.pdf.

Euractiv. 2013a. "Hedegaard: More 2030 Climate Targets Would Be 'Wise."' EurActiv.com. 2013. http://www.euractiv.com/energy/hedegaard-2030-climate-targets-w-news-530979.

_ 2013b. "Oettinger Hails 'Wide Agreement' on 2030 Energy Targets, but Doubts Persist.” Euractiv.com. 2013. http://www.euractiv.com/energy/2030-energy-targetdoubts-oettin-news-530613.

Eurelectric. 2009. "Power Choices: Pathways to Carbon-Neutral Electricity in Europe by 2050." 2009. www.eurelectric.org/PowerChoices2050/.

Eurogas. 2011. "Eurogas Roadmap 2050."

European Climate Foundation. 2010. "Roadmap 2050: A Practical Guide to a Prosperous, Low-Carbon Europe (Volume 2).” Europe. 2010. https://doi.org/10.2833/10759. 
European Commission. 2011a. "A Roadmap for Moving to a Competitive Low Carbon Economy in 2050." 2011. https://doi.org/10.1002/jsc.572.

. 2011b. "Energy Roadmap 2050.” 2011.

https://ec.europa.eu/energy/sites/ener/files/documents/2012_energy_roadmap_2050_en_ 0.pdf.

. 2013. "Green Paper: A 2030 Framework for Climate and Energy Policies." Brussels. 2013. http://ec.europa.eu/transparency/regdoc/rep/1/2013/EN/1-2013-169-EN-F1-1.pdf.

- 2014a. "Impact Assessment - A Policy Framework for Climate and Energy in the Period from 2020 up to 2030.” 2014. http://ec.europa.eu/smart-

regulation/impact/ia_carried_out/docs/ia_2014/swd_2014_0015_en.pdf.

- 2014b. "Minutes of the 2072nd Meeting of the Commission Held in Brussels (Berlaymont) on Wednesday 22 January 2014." 2014.

http://ec.europa.eu/transparency/regdoc/rep/10061/2014/EN/10061-2014-2072-EN-F11.Pdf.

-. 2014c. "Proposal for the Establishment and Operation of a Market Stability Reserve for the Union Greenhouse Gas Emission Trading Scheme and Amending Directive 2003/87/EC.” 2014. http://eur-lex.europa.eu/legalcontent/EN/TXT/PDF/?uri=CELEX:52014PC0020\&from=en.

2016. "The EU Emissions Trading System (EU ETS)." Brussels. https://doi.org/10.2834/55480.

European Council. 2007. "Brussels European Council 8/9 March 2007 Presidency Conclusions."

_. 2009. "29/30 October 2009: Conclusions." 2009.

http://www.consilium.europa.eu/uedocs/cms_data/docs/pressdata/en/ec/110889.pdf.

- 2014. "European Council (23 and 24 October 2014) Conclusions on 2030 Climate and Energy Policy Framework.” 2014.

http://www.consilium.europa.eu/uedocs/cms_data/docs/pressdata/en/ec/145397.pdf.

European Gas Advocacy Forum. 2011. "Making the Green Journey Work: Optimised

Pathways to Reach 2050 Abatement Targets with Lower Costs and Improved Feasibility." Brussels. http://www.gazprom-

$\mathrm{mt} . \mathrm{com} /$ WhatWeSay/OurPerspectives/Documents/making_the_green_journey_work.pdf

European Parliament. 2014. "Decision of the European Parliament and of the Council Concerning the Establishment and Operation of a Market Stability Reserve for the Union Greenhouse Gas Emission Trading Scheme and Amending Directive 2003/87/EC." Brussels. https://doi.org/10.1007/s13398-014-0173-7.2.

EWEA. 2014. "Position on the Backloading Proposal."

Fuchs, Doris, and Berenike Feldhoff. 2016. "Passing the Scepter, Not the Buck: Long Arms in EU Climate Politics." Journal of Sustainable Development 9 (6): 58. https://doi.org/10.5539/jsd.v9n6p58.

Greenpeace. 2010. Energy [R] evolution: A Sustainable World Energy Outlook. 
Groenenberg, H., F. Ferioli, S Heuvel, and M.T.J. Kok. 2008. "Climate, Energy Security and Innovation; An Assessment of EU Energy Policy Objectives.” Policy Studies, no. April. https://www.ecn.nl/publications/PdfFetch.aspx?nr=ECN-E--08-006.

Grubb, Michael, Will McDowall, and Paul Drummond. 2017. "On Order and Complexity in Innovations Systems: Conceptual Frameworks for Policy Mixes in Sustainability Transitions.” Energy Research \& Social Science 33 (November). Elsevier: 21-34. https://doi.org/10.1016/J.ERSS.2017.09.016.

Haas, Ernst B. 1958. The Uniting of Europe: Political, Social and Economic Forces, 19501957. Reprint, Notre Dame, IN: University of Notre Dame Press, 2003.

Helm, Dieter. 2012. The Carbon Crunch. New Haven and London: Yale University Press.

Herweg, Nicole. 2015. "Against All Odds: The Liberalisation of the European Natural Gas Market-A Multiple Streams Perspective." In Energy Policy Making in the EU: Building the Agenda, edited by Kai Schulze Jale Tosun, Sophie Schmitt, 87-105. Springer. https://doi.org/10.1007.

_. 2016. "Explaining European Agenda-Setting Using the Multiple Streams Framework: The Case of European Natural Gas Regulation." Policy Sciences 49 (1). Springer US: 13-33. https://doi.org/10.1007/s11077-015-9231-z.

Herweg, Nicole, Christian Huß, and Reimut Zohlnhöfer. 2015. "Straightening the Three Streams: Theorising Extensions of the Multiple Streams Framework." European Journal of Political Research 54 (3): 435-49. https://doi.org/10.1111/1475-6765.12089.

Hone, David. 2017. Putting the Genie Back: Solving the Climate and Energy Dilemma. Bingley: Emerald.

IETA. 2012. "Briefing on the EU's Emissions Trading Scheme."

Inoguchi, Takashi. 1979. "Political Surfing over Economic Waves: A Simple Model of the Japanese Political Economic System in Comparative Perspective." In Eleventh World Congress of the International Political Science Association, Moscow, 1960-80.

_ 2016. "The Emergence of Comparative Politics in Japan.” Asian Journal of Comparative Politics 1 (1): 77-87. https://doi.org/10.1177/2057891115618450.

Jones, Bryan D, and Frank R. Baumgartner. 2005. The Politics of Attention: How Government Prioritizes Problems. University of Chicago Press.

Jones, Michael D., Holly L. Peterson, Jonathan J. Pierce, Nicole Herweg, Amiel Bernal, Holly Lamberta Raney, and Nikolaos Zahariadis. 2016. "A River Runs Through It: A Multiple Streams Meta-Review.” Policy Studies Journal 44 (1): 13-36. https://doi.org/10.1111/psj.12115.

Kayser, Mark Andreas. 2005. "Who Surfs, Who Manipulates? The Determinants of Opportunistic Election Timing and Electorally Motivated Economic Intervention." American Political Science Review 99 (1): 17-27. https://doi.org/10.1017/S0003055405051464.

Kingdon, John W. 2010. Agendas, Alternatives, and Public Policies. 2nd Editio. Harlow: Pearson.

Klüver, Heike. 2011. "Lobbying in Coalitions: Interest Group Influence on European Union 
Policy-Making." Nuffield's Working Papers Series in Politics. 2011.

https://www.nuffield.ox.ac.uk/politics/papers/2011/Heike Kluever_working paper_2011_04.pdf.

Klüver, Heike, Christine Mahoney, and Marc Opper. 2015. "Framing in Context: How Interest Groups Employ Framing to Lobby the European Commission." Journal of European Public Policy 22 (4): 481-98. https://doi.org/10.1080/13501763.2015.1008550.

Lehmann, Paul, and Erik Gawel. 2013. "Why Should Support Schemes for Renewable Electricity Complement the EU Emissions Trading Scheme?" Energy Policy 52 (January): 597-607. https://doi.org/10.1016/j.enpol.2012.10.018.

Meadowcroft, James. 2009. "What about the Politics? Sustainable Development, Transition Management, and Long Term Energy Transitions.” Policy Sciences 42 (4): 323-40. https://doi.org/10.1007/s11077-009-9097-z.

Mintrom, Michael, and Joannah Luetjens. 2017. "Policy Entrepreneurs and Problem Framing: The Case of Climate Change." Environment and Planning C: Politics and Space, 1-16. https://doi.org/10.1177/2399654417708440.

Mintrom, Michael, and Phillipa Norman. 2009. "Policy Entrepreneurship and Policy Change.” Policy Studies Journal 37 (4): 649-67. https://doi.org/10.1111/j.15410072.2009.00329.x.

Mitchell, Catherine. 2010. The Political Economy of Sustainable Energy. 2nd ed. Basingstoke: Palgrave Macmillan.

Mitchell, Catherine, D. Bauknecht, and Peter M. Connor. 2006. "Effectiveness through Risk Reduction: A Comparison of the Renewable Obligation in England and Wales and the Feed-in System in Germany." Energy Policy 34 (3): 297-305. https://doi.org/10.1016/j.enpol.2004.08.004.

Mucciaroni, Gary. 1992. "The Garbage Can Model \& the Study of Policy Making: A Critique.” Polity 24 (3): 459-82. https://doi.org/10.2307/3235165.

Oberthür, Sebastian. 2011. "The European Union's Performance in the International Climate Change Regime." Journal of European Integration 33: 667-82. https://doi.org/10.1080/07036337.2011.606690.

Politico. 2014. "European Renewable-Energy Lobby Liquidated.” Politico.eu. 2014. http://www.politico.eu/article/european-renewable-energy-lobby-liquidated/.

Quirk, Paul J. 1989. "The Cooperative Resolution of Policy Conflict.” American Political Science Review 83 (3): 905-21. https://doi.org/10.2307/1962066.

Rawcliffe, Peter. 1998. Environmental Pressure Groups in Transition. Manchester University Press.

Ringel, Marc. 2006. "Fostering the Use of Renewable Energies in the European Union: The Race between Feed-in Tariffs and Green Certificates." Renewable Energy 31 (1): 1-17. https://doi.org/10.1016/j.renene.2005.03.015.

Rochefort, David A., and Roger W. Cobb. 1994. The Politics of Problem Definition: Shaping the Policy Agenda. University Press of Kansas. 
Skjærseth, Jb, and Jørgen Wettestad. 2010. "Fixing the EU Emissions Trading System? Understanding the Post-2012 Changes." Global Environmental Politics 10 (4): 101-23. https://doi.org/10.1162/GLEP_a_00033.

Solomon, Barry D., and Karthik Krishna. 2011. "The Coming Sustainable Energy Transition: History, Strategies, and Outlook.” Energy Policy 39 (11): 7422-31. https://doi.org/10.1016/j.enpol.2011.09.009.

Szulecki, Kacper, Severin Fischer, Anne Therese Gullberg, and Oliver Sartor. 2016.

"Shaping the 'Energy Union': between National Positions and Governance Innovation in EU Energy and Climate Policy." Climate Policy 16 (5): 548-67. https://doi.org/10.1080/14693062.2015.1135100.

Tietenberg, Thomas H. 1985. Emissions Trading, an Exercise in Reforming Pollution Policy. Resources for the Future.

UNFCCC. 2012a. "Report of the Conference of the Parties on Its Seventeenth Session, Held in Durban from 28 November to 11 December 2011: Addendum 1." Durban. https://doi.org/FCCC/CP/2011/9/Add.1.

- 2012b. "Report of the Conference of the Parties on Its Seventeenth Session, Held in Durban from 28 November to 11 December 2011: Addendum 2." Durban.

- 2014. "Report of the Conference of the Parties on Its Nineteenth Session, Held in Warsaw from 11 to 23 November 2013." https://doi.org/10.1016/j.biocon.2006.08.013.

Voltolini, Benedetta, and Rainer Eising. 2016. "Framing Processes and Lobbying in EU Foreign Policy: Case Study and Process-Tracing Methods." European Political Science, 1-15. https://doi.org/10.1057/eps.2016.18.

Voß, Jan-Peter. 2007. "Innovation Processes in Governance: The Development of 'Emissions Trading' as a New Policy Instrument.” Science and Public Policy 34 (5): 329-43. https://doi.org/10.3152/030234207X228584.

Voß, Jan-Peter, and Arno Simons. 2014. "Instrument Constituencies and the Supply Side of Policy Innovation: The Social Life of Emissions Trading." Environmental Politics 23 (5). Routledge: 735-54. https://doi.org/10.1080/09644016.2014.923625.

Weible, Christopher M., and Edella Schlager. 2016. "The Multiple Streams Approach at the Theoretical and Empirical Crossroads: An Introduction to a Special Issue." Policy Studies Journal 44 (1): 5-12. https://doi.org/10.1111/psj.12143.

Wettestad, Jørgen. 2014. "Rescuing EU Emissions Trading: Mission Impossible?," no. May: 64-81. https://doi.org/10.1162/GLEP.

Wettestad, Jørgen, and Torbjørg Jevnaker. 2016. Rescuing EU Emissions Trading: The Climate Policy Flagship. London: Palgrave Macmillan.

Winkel, Georg, and Sina Leipold. 2016. "Demolishing Dikes: Multiple Streams and Policy Discourse Analysis.” Policy Studies Journal 44 (1): 108-29. https://doi.org/10.1111/psj.12136.

Woerdman, Edwin. 2004. "Path-Dependent Climate Policy: The History and Future of Emissions Trading in Europe." European Environment 14 (5): 261-75.

https://doi.org/10.1002/eet.362. 
Woodman, Bridget, and Catherine Mitchell. 2011. "Learning from Experience? The Development of the Renewables Obligation in England and Wales 2002-2010." Energy Policy 39 (7): 3914-21. https://doi.org/10.1016/j.enpol.2011.03.074.

WWF. 2012. "Re-Energising Europe, Cutting Energy Related Emissions the Right Way." 2012.

http://awsassets.panda.org/downloads/cutting_energy_related_emissions_the_right_way _.pdf.

Ydersbond, Inga Margrete. 2016. "Where Is Power Really Situated in the EU?” Oslo.

Zahariadis, Nikolaos. 2008. "Ambiguity and Choice in European Public Policy." Journal of European Public Policy 15 (4): 514-30. https://doi.org/10.1080/13501760801996717.

- 2014. "Ambiguity and Multiple Streams." In Theories of the Policy Process, edited by Paul A. Sabatier and Christopher M. Weible, 3rd ed., 25-57. Boulder, Colarado: Westview Press. 